The rural geographies of Barbara Kingsolver's Prodigal Summer

\author{
Alistair Fraser \\ Department of Geography \\ National University of Ireland Maynooth \\ alistair.fraser@nuim.ie
}

Forthcoming in Journal of Rural Studies. 


\title{
The rural geographies of Barbara Kingsolver's Prodigal Summer
}

\begin{abstract}
Academics are undoubtedly at the forefront of efforts to understand and communicate the sorts of far-reaching contemporary changes that make rural space so heavily contested. However, numerous other writers are engaged in contemporary debates about rurality and, among them all, Barbara Kingsolver stands out as particularly important. As such, this paper uses her novel Prodigal Summer to consider how Kingsolver imagines and portrays contested rural geographies. Analytically, the approach develops current ideas in literary geography by asking about the "scalar" poetics and underlying, unwritten causal geographies of Prodigal Summer. Via a careful consideration of these issues in the novel, the paper discusses how the world Kingsolver imagines and depicts overlaps with contemporary debates in rural studies.
\end{abstract}

\section{Keywords}

Contested ruralities; literary geography; scale; causality; Barbara Kingsolver

\section{Introduction}

The backdrop to this paper is what I understand to be the contemporary global politics of the rural. This is a politics defined by the current global strength of neoliberal capitalism, which produces unprecedented material inequality and makes it conceivable and feasible for those with significant wealth to move into and seek to control rural space. Evidence of such outcomes can be found across the social sciences, ranging from processes of rural gentrification in the 'global north', as documented by scholars of rural studies, for example (e.g. Phillips, 1993; Phillips, 2004; Darling, 2005); to the so-called 'land grabs' taking place in Sub-Saharan Africa and elsewhere, which is increasingly emphasized in the area of agrarian 
political economy (e.g. see Akram-Lodhi, 2012; McMichael, 2012; Zoomers, 2010; White et al, 2012). Of course, because such far-reaching changes in rural space are always contested, there are vigorous debates about the role of neoliberal capitalism in the making of rurality. For some, no doubt, neoliberal capitalism is a progressive force, one that will rationalize the use of rural space and produce more efficient outcomes regarding food production, say, or the use of natural resources (e.g. World Bank, 2008). In contrast, many others interpret the contemporary global politics of the rural as requiring arguments and action that will either limit its most problematic effects, or bring an end to neoliberal capitalism all together (e.g. see Moyo and Yeros, 2005; Petras, 2006; McMichael, 2008).

So there is a debate and a diverse range of scholars with interests that connect with rural studies are shaping how it unfolds. But to focus solely on scholarly interventions here risks overlooking the role other writers might play in shaping the contemporary global politics of the rural. For example, regarding the importance of food production in the contemporary period, the work of journalists (e.g. Pollan, 2008) or so-called celebrity chefs (e.g. see Piper, 2013) might be considered. Then there are the interventions of politicians, perhaps most notably Al Gore, whose book, An Inconvenient Truth (Gore, 2006a) and subsequent film (Gore, 2006b) have shaped the climate change debate, which overlaps in numerous ways with the sorts of politics at issue here. But for the purposes of this paper, I suggest that novelists deserve our attention and that Barbara Kingsolver is one standout contributor author to consider.

Throughout her work, Kingsolver takes on and weaves together beautiful stories around significant processes that shape rural space, as well as society more generally. For example, in her most recent book, Flight Behaviour (2012), Kingsolver challenges readers to dwell upon 
the cross-border politics of climate change, using the case of the Monarch Butterfly and its extraordinary migratory patterns to connect and write about the parallels of rural change in the US and Mexico. In addition, The Poisonwood Bible (1998), her most popular book, forces readers to consider how life in rural Zaire/Congo changes a missionary family from the US; in so doing, she confronts the complicity of the US government in some of the most horrific changes that occurred in Congo in the 1960s and helped set in motion that country's violent last half-century. Flight Behaviour and The Poisonwood Bible (as well as some of her nonfiction, in particular Animal, Vegetable, Miracle) certainly raise important issues about the making of rural space, but Prodigal Summer (2000) is perhaps the most relevant to scholars of rural studies (for commentary on this novel, see Hanson, 2010; Jacobson, 2010; Jones, 2006; Leder, 2009; Wenz, 2003) and is the focus of this paper.

In brief, Prodigal Summer is about Lusa Landowski, a lepidopterist who arrives with Cole Widener, her new husband, to live on his farm in fictional Zebulon County in rural Appalachia. Lusa is widowed soon after arriving and the rest of the novel is about her struggles to generate a way of living that suits her ethics, despite social relations with family, community, and actors at other geographical scales that undermine the vision she tries to make real. This is a novel about resistance. But Lusa is not the only character whose resistance and bravery Kingsolver recounts. Rather, Prodigal Summer also traces the challenges faced, and in some ways overcome, by two other strong female characters, Deanna Wolfe and Nannie Rawley. These three women - Lusa, Deanna, and Nannie - encounter and find ways of managing problematic processes shaping the rural spaces they help constitute. Among other issues, they confront: numerous forms of environmental change; the power of agribusiness relative to small-scale farmers; the over-use of agri-chemicals and concomitant worries about pollution and contamination; the challenges facing organic production; and 
intra-household and intra-family tensions regarding normative practices and the adoption of (what rural studies scholars have referred to as) "farm adjustment strategies" (e.g. Ilbery, 1991; Evans, 2009). Given its engagement with these sorts of issues, the novel provokes debate about the way rural space is changing today and challenges readers to consider how alternative geographical configurations might emerge from those same spaces. Clearly, it also speaks to the sorts of debates that matter in contemporary rural studies, as well as other literatures navigating the contemporary global politics of the rural.

In considering Prodigal Summer, the approach taken here draws inspiration from some recent contributions in the area of literary geography (e.g. Hones, 2008; Kearns, 2005-06; Saunders, 2010). From the idea that understanding the spatial event of the text can open up opportunities to consider how spatial poetics operate, I suggest that a scalar poetic can be explored in Prodigal Summer. As will be discussed, Kingsolver deploys a particular scalar imaginary but one that also allows readers to better understand the complexity of causality in rural space, especially as it applies to Lusa, the story's main character. What matters in the end for Lusa is that the rural place she finds herself in is stretched out, absolutely "transrural" (Askins, 2009), and hence inevitably the product of what Doreen Massey (1999) has famously referred to as "happenstance juxtapositions". The possibility of Lusa transforming her life hinges on the way she flexibly navigates this specific geographical configuration. In doing so, she confronts the contemporary global politics of the rural and via her success she demonstrates that others can do likewise. Thus, in Prodigal Summer, scholars of rural studies can find a writer communicating through fiction the significance of many of the same processes and patterns that academic literature has explored, which makes an analysis of this part of Kingsolver's work all the more important. But Prodigal Summer is also a rich text for scholars of literary geography. With regards to its scalar poetic and the unwritten causality shaping how the text 
can be read, the text opens up new issues for consideration among literary geographers, as I now begin to discuss in more detail.

\section{Scale, causality and literary geography}

Critical attention to texts - ranging from the imaginative to the scientific - continues to present opportunities to 'map words' in ways that contribute to contemporary geographical debates (Saunders, 2010), and expand "understanding of the spatiality of social life" (Brosseau, 2009 p.217). In a recent review of literary geography which celebrates its continued relevance, Saunders (2010) nevertheless calls for a renewed effort to analyze and reveal the full breadth of geographies underpinning and constituting the "textual encounter" (Livingstone, 2005 p.95) between author and reader. Literary geography focuses on what literature knows, the practices used to make and consume it, and the spatial poetics of a text. It follows that literary geographers can ask how author and reader meet up with and negotiate each other; how a wide range of practices used to produce and consume literature shape the experience of that encounter; and how the spatial poetics within, and cutting their way through, a text affect its content and significance.

For Hones (2008), these possible lines of inquiry can come together through her idea of the 'spatial event of a text'. In her view, a text is first of all what we see on the page (or on the screen) but this encountering event also has to be seen as existing alongside a wide range of other geographies - other relations and movements, many of them accidental, unintentional lurking behind and emerging from it. There is, for example, the context in which the author writes and in which readers read. Then there are the networks mobilised to produce, print, distribute, sell, promote, and discuss texts. In other words, from the spatial event of the text an inherently open constellation of relations takes shape. There is this sense that a text generates 
an "inherent indeterminacy" (Crang, 2009 p.1), a diverse, infinitely large number of possible interpretations of its meanings, as well as a wide open expanse of possible presuppositions for its production in the first place. What we might refer to as the 'first opening of the text' means that lurking behind and emerging from the spatial event of the text - from its impact - is a shattering of fragments: a vast openness and opening that creates room for an unknowable range of criticism, discussion and debate.

For literary geography, one among many other ways to engage with the first opening of the text is to explore its spatial poetics. The point of thinking about spatial poetics is to demonstrate "the significance of space to the production of meaning" (Saunders, 2010 p.447); that is, it entails a type of analysis that can reveal hidden or less audible geographies that shape readerly engagement. For example, in Christina Stead's Seven Poor Men of Sydney (1999), Edquist (2009) detects and sheds light on imprecise geographies of wandering, centre and periphery, and death and horror (p.347) that locate Sydney relative to Australia more generally in the early twentieth century, but also in a world of "travel, shipping and the oceans" (p.348). Stead's characters "not only walk the streets of Sydney but also remember, dream, hallucinate and recount other places and spaces as well, all of which form a part of their lived experience and the geography of the novel" (p.348). Bringing such spatialities to light then presents opportunities to say something about the broader geographies that underpin the literary encounter, which Kearns (2005-2006) demonstrates in his study of James Joyce's Ulysses. Drawing attention to spatial metaphors of circulation, labyrinth and palimpset within the text's background, Kearns discusses how these relate to Joyce's concerns about nationalism, religion, and colonialism in early twentieth century Ireland. The spatial poetics of Ulysses hint at the imagination of an alternative Dublin to the city Joyce presented; an alternative that Kearns urges readers to consider, however difficult a task that might be. In so 
doing, he demonstrates that imagining and understanding 'the significance of space to the production of meaning' within a text presents opportunities for the analyst - geographer or not - to look beyond the text and relate it to the challenges and dilemmas facing the sorts of societies and social processes that authors depict.

If the first opening of the text allows literary geographers to tear it apart and spot the patterns and the stitches that make it come together, that inherent openness also allows a questioning of the broader meaning of the text to the production of the sorts of spaces that give it a chance to exist in the first place. Thus, literary geography can explore spatial poetics (or any other particular aspect) to reveal the significance of space to the production of meaning 'upstream' of the reader's engagement, but also 'downstream' once it has been published. In other words, as Hones (2008) might put it, a somewhat technical analysis of poetics can help see what the text is made of but it can also create opportunities to contribute to a richer understanding of what lurks behind and emerges from the spatial event of the text. In this way, the first opening of the text offers a chance to say something about the constellation of possible presuppositions and fragments, of the contextual considerations before production and the meanings that might emerge from its consumption.

There are numerous areas of literature in which just such an exploration of poetics can occur; but there are also some exciting new lines of inquiry to consider when trying to figure out how poetics might matter. According to Saunders (2010 p.449), one issue for literary geography as a whole might be "the need to consider more fully the appropriateness of scale as an analytical framework ". Scale matters in numerous ways. There are, for example, the various interrelationships between the scale of the text (such as the sentence, paragraph, or chapter) and the scale of presentation (such as whether the text focuses on individual 
consciousness, the home, city or region) (p. 449). In The Man in the High Castle (Dick 1962), Hones (2011 pp.690-691) notes that "the frequent absence of definite and indefinite articles in both direct and free indirect discourse" at the smaller scale, and "multiple focalizations and voices" at the larger scale shapes the narrative space of the novel and reflects Dick's "impression of how fiction would be written in this alternative world". Scale can also matter methodologically, something that scholars need to figure into their approaches. Livingstone (2005 p.99) has noted this point regarding enquiry into the historical geography of science, by asking what should be the "precise scale of analysis [:] site, region, nation, globe [?"]. Additionally, there remains a lot to say about how different scales (such as the body, the home, or the nation) interact with axes of difference like class, gender, or race (for an excellent and groundbreaking example, see McKittrick, 2000).

For its part, this paper asks how scale might offer a way to analyse poetics, that is, the paper explores the scope that exists for literary geography to dwell not just on the spatial, but more accurately the scalar poetics of texts. Consider here the obvious point that imaginative works use a range of scalar poetics to communicate and create meaning. A novel is fundamentally shaped by the author's choice of focusing on an individual, a household, a community or some other geographical scale such as a city or a nation-state. So, too, are decisions about what should be the scale at which actions unfold. Perhaps an individual will be the focus of a novel, but will his or her story then develop only within a household, or all across a city or the world? In the decision to organize a novel around a specific 'scale division', an author is shaping the way the text unfolds, much in the same way that it matters how places and spatial arrangements are imagined and used. The way life is depicted as unfolding at different geographical scales can be analysed, interpreted, and built upon in explorations of the relationship between author, text, and reader. Thus, at issue for critical geographical analyses 
of imaginative texts is the question of how a scalar poetic comes into play, how it matters in the social world presented by the author, and whether and how it gives the text power and significance. As such, the overarching question animating this paper asks "What is the significance of scalar poetics to the production of meaning in imaginative texts?"

A secondary question informing this paper develops from the first but also from the idea that a consideration of poetics (or meaning, or any other aspect) in a text engages with the first opening of the text. Whereas it is obvious that the creation of an imaginative text entails authorial decisions about what should happen and how change occurs, it also needs to be pointed out that some changes occur - some events and processes are caused - off-stage, as it were. Without question, the "world of the novel is made up of locations and settings, arenas and boundaries, perspectives and horizons" (Daniels and Rycroft, 1993 p.460; quoted in Edquist, 2009 p.343); there is a social world with characters, relations, places, movements, and so on. But what readers encounter is only ever a slice of that world, never everything the author imagines and nor can the author imagine everything because in that "inherent indeterminacy" (Crang, 2009 p.1) of understanding and interpretation, readers imagine and explain that off-stage causality in their own multiple ways.

It follows from all this that there is a broader causality behind the making of events that the author might not dwell upon extensively, but which readers are certainly free to consider. This begs all sorts of questions about the imagined geography of a text. The social world presented by the author has places and configurations and is depicted using voices or metaphors - hence, a diverse and necessarily complex geography is imagined and introduced and then encountered by readers - but, within that world, a wide range of critical processes unfold, key changes occur, and all-important dramatic events take place - and by no means all of them are 
fully dwelt upon by the author. This unwritten causality generates a second opening of the text. The first, as noted earlier, is about what is on the page or screen, about the constellation of relations lurking behind or emerging from what authors publish. The second opening is about another dimension of constellations dealing with the unwritten processes and events that happen elsewhere in the social world of the text.

For literary geographers, at least, what has to be at issue in engaging with this second opening is a set of questions about the sort of geography that shapes what happens off-stage. Such analyses might therefore ask "What might produce the unwritten world shaping events and processes in imaginative texts; that is, what causes the critical (i.e. central, most dramatic) processes to unfold the way they do?" It then follows that conclusions might be drawn about how that imagined world - that imagined causality - contributes to contemporary debates about related social issues. In other words, as with the first opening of the text and the infinite openness generated by the inevitability of multiple readings and understandings, the second opening of the text about unwritten causality also creates room for infinitely open reflections, considerations, and interventions.

Based on the above, this paper aims to consider the scalar poetics of imaginative texts, as per the first opening of the text. And in line with the idea of a second opening of the text, it then seeks to examine what sort of a geography can shape the underlying, unwritten social worlds in imaginative literature. As noted in the Introduction, the text in question here is Barbara Kingsolver's Prodigal Summer. Using it entails a trade-off. On the one hand, it does not satisfy the call for contributions in literary geography to move beyond the tendency to deal with a single author/text/place (e.g. see Hones, 2008 p.1312). Yet, on the other hand, Prodigal Summer is a useful text to consider in literary geography insofar as it raises questions about 
contemporary rurality (and the related politics) which the field largely neglects in favour of dealing with urban settings and issues.

My focus will be on three key moments in the novel that have not been dwelt upon to any great extent in the literature on Prodigal Summer, nor in the general literature on Kingsolver (e.g. see Hanson, 2010; Jacobson, 2010; Jones, 2006; Leder, 2009; Wenz, 2003). It is absolutely essential to emphasise (not least because of that inherent indeterminacy of the text) that these are not necessarily the most important moments. At least from the perspective of rural studies, Prodigal Summer is such a rich text that any number of other twists and turns could be considered. Rather, the first two moments (dealt with in Section 3 below) work because they help explain the significance of the scalar poetic in Prodigal Summer and the third (discussed in Section 4) is helpful because it draws attention to the unwritten causality and underlying rural geography that shapes how the text emerges.

\section{Scalar poetics in Prodigal Summer}

The stories of three progressive female characters - Deanna Wolfe, Nannie Rawley and Lusa Landowski - and Garnett Walker, its main male character, unfold through the pages of Prodigal Summer. The novel has three interchanging parts, each given a title to indicate which characters are in focus. 'Predators' focuses on Deanna Wolfe, a forest ranger on Zebulon Mountain. 'Old Chestnuts' is about Garnett Walker, a retired teacher and his neighbour Nannie Rawley, another retiree who runs an organic orchard on her piece of land. Finally, 'Moth Love' tells Lusa Landowski's struggle to change the direction of the farm business she inherits after Cole's death. In depicting the fictional Zebulon County, Kingsolver imagines a place in which human-environment relations are central, in part to achieve her aim of delivering ecological lessons about contemporary rural space (e.g. see Leder 2009; Wenz, 
2003). Alongside this strong ecological emphasis, the novel also says a lot about social processes: this is, after all, a novel about resistance against normalized practices in rural space, about three women who search for alternative ways of making their lives amidst the sort of structural constraints that many others find difficult to overcome.

Kingsolver's capacity to blend together ecological and social lessons whilst telling a captivating story about life in rural Appalachia is certainly central to the novel's success. But also important, I argue, is a striking scalar poetic that Kingsolver uses to imagine and represent Zebulon County. All three stories take place within this one county and Kingsolver does say a lot about that overall place throughout each part of the book; yet the stories in each sub-plot unfold at a different scale and this scalar approach to depicting the action helps readers grasp the sorts of difficulties faced by Lusa, the central character.

Deanna's story, for example, occurs on and across Zebulon Mountain, with the action unfolding on trails, cliffs, as well as bridges over creeks, in clearings, groves and hollows. Kingsolver evocatively depicts the vastness of the space and the room it provides for Deanna and her newfound lover Eddie Bondo to bump into and avoid each other. From the mountain, life in the county and beyond - life "down there" (p.196) - appears distant, different, yet still connected, still with meaning. There is, then, this sense of expanse and even generality in Deanna's story, a generality explored via the particular social configuration Kingsolver creates. As in Lusa's and Nannie's stories, Deanna is cognisant of and frequently confronts a range of tensions between the logics and processes making human and non-human worlds; but when Eddie appears on the scene with his radically different views on conservation, hunting, and predators (especially coyotes), these tensions are brought front and centre and then given a highly personal and emotional twist when Lusa falls for Eddie; a twist, moreover, that 
overlaps in numerous ways with many other depictions of reproduction in the novel (see Leder, 2009 pp.229-230).

Deanna - seemingly embodying Kingsolver's outlook and her interpretation of the scientific studies that helped her write Prodigal Summer (e.g. see Leder, 2009: 233) - values the input that predators can make to the vitality and stability of the mountain's ecosystem. Thus, when she becomes aware of coyotes in the Forest Park, her inclination is to protect them from local farmers and other hunters. Her stance comes into direct conflict with Eddie who, like Deanna, loves the forest, takes an interest in flowers, insects, and birds, but hates coyotes; his farming background in Wyoming taught him to do so. Throughout their story, therefore, Deanna and Eddie negotiate this difference of opinion, all whilst developing an intense sexual relationship. In the end, Eddie ultimately agrees not to hunt the coyotes but his views on their predation compel him to leave Deanna.

In telling their story and exploring their differences, Kingsolver manages to introduce to readers a broad debate about humans and the environment, the food chain, the virtues of conservation, the perils of over-hunting, and even the possibility of co-existence between farming and predators. Although Lusa and Nannie also engage in related debates elsewhere in the novel, theirs are more focused, more specific to the dilemmas facing farmers as they try to stay on the land. Rather, here on the mountain, the macro scale of the novel is introduced and explored: the generality of tensions between what humans can and want to do, and the environmental impacts and consequences of the changes set in motion by hunting (such as booming populations of smaller animals, many of them pests) or agriculture (over-use of pesticides killing insects and starving birds) or trade (introduction of invading species, such as the fungus which killed the Chestnut trees). Through the human and non-human "collision of 
strangers" (Kingsolver, 2000 p.6 \& 26) on the vast spaces of Zebulon mountain - indeed because of the precise possibility and even the inevitability of such collisions - Kingsolver creates for Deanna a complicated, dynamic and intense set of scenarios which end in her leaving the mountain pregnant but single. Yet, through the same collisions and scenarios, Kingsolver also sets the general scene for the other stories in the novel, a context scarred by the socio-environmental history of the rural U.S., the sorts of ecological pressures that have shaped the way places such as Zebulon County have developed, the critical battles that continue to occur over control of space, such as whether to pursue regarding coyote eradication (see Wenz, 2003), and the ongoing effort to recover and restore a better ecological balance for all species, not just for humans.

If Deanna's story on the mountain is the macro scale of the novel, then Nannie's struggle occurs at the 'micro' scale. Nannie's story centres on a fence between her land and that of Garnett Walker, her neighbour. This boundary between them is all-important because Garnett freely sprays pesticides all along it, which worries Nannie because the chemicals disturb her organic orchard. In the process of describing how the two neighbours negotiate their shared boundary, Kingsolver is able to provide further contextual information to readers about the way life occurs in Zebulon County. Garnett is no outlier: his views on ecology and society are thoroughly within the mainstream. Kingsolver recounts some of his thoughts on his neighbour, almost as if they reflect what might be the general perception of Nannie's practices: that is, "her Unitarian beliefs, feminist ideals, and organic-farming practices incense him" (Jones, 2006 p. 91), and it seems they might irritate others in the area. In the sub-plot around Nannie and Garnett, Kingsolver presents Nannie's effort to stand up to the normalized practices of her neighbour, which in turn lets readers consider how resistance at the micro scale might lead to positive changes in rural places such as the fictional Zebulon County. But more generally, 
Kingsolver uses Nannie's story to lay out contextual information about the county, which helps readers understand the struggles that Lusa will face.

Lusa is the book's hero. She achieves the most and probably has the brightest future, although Kingsolver signs off the book with a sense of optimism for all three characters. Readers are supposed to cheer for Lusa, not least because her struggle is the most profound given the material necessity to find a new way of farming the land. Lusa is also a newcomer to Zebulon County and Kingsolver wants readers to gain a strong sense for just how difficult it would be for someone like her - an educated woman with an urban background, with liberal and cosmopolitan sensibilities and viewpoints - to move into this new place, regardless of the circumstances that she faces. Over the course of the summer, Lusa grapples with many of the same structures and processes - such as patriarchy, 'conventional agriculture', and mainstream understandings of how to use the land - faced by Deanna and Nannie. The significance of the other two stories in the book is that they help readers understand just how difficult it is going to be for Lusa to change the farm business she inherits. For example, from Deanna's story we know about the general context, of a socio-environmental history that privileges destructive and dominating human interventions, rather than the sort of conservation and careful nurturing that Lusa believes is possible on her land. And from Nannie's story we know about the dominant local attitudes towards pesticides, say, and more generally about how best to farm (attitudes Lusa also encounters via relations with some of her brothers-in-law). The general and then the local and more specific. It is significant, then, that Lusa's story is nestled in between the macro and micro scales of the novel: in between Deanna's struggles on the mountain and Nannie's debates over a fence, Lusa's summer unfolds on her individual farm unit, although relations with the broader area still matter immensely. Using the first of the 
three moments at issue in the paper, I now discuss in more detail how this scalar poetic contributes to the novel's construction and power.

\subsection{Lusa's trap}

Following Cole's death, the question Lusa has to answer is what she should do with the farm. She has options. One is to walk away. She was not married long and Cole's family are not as welcoming as they might be. If she is to stay, she has to find a way to make the farm unit survive. Cole was not managing. Like many other small-scale farmers, he had taken work off the farm and it is during one such shift that he dies. Lusa could raise money by logging her share of the mountain, the importance of which to the overall ecology of the county Kingsolver has made clear by referring to Deanna's story. But Lusa shakes her head when Jewel, her sister-in-law, proposes this: "I couldn't log this hollow. . . . I will not cut down those trees. I don't care if there's a hundred thousand dollars' worth of lumber on the back of this farm, I'm not selling it. It's what I love best about this place" (Kingsolver, 2000 p.123). By deciding to stay and refusing to log, Lusa is faced with the same sort of farming options facing Cole and in Zebulon County that means tobacco - "the only reliable crop around here you can earn enough from to live off a five-acre bottom, in a county that's ninety-five percent too steep to plow" (p.122).

Cole's family want to begin planting soon after the funeral. However, Kingsolver has something else in mind for her hero. This is a critical moment in the novel. Lusa could stick with tobacco. And given the difficulties many other tobacco farmers face, the novel could have been about the hard path tobacco farmers must take each summer. As Lusa notes: 
"I know why every soul in this end of three states grows tobacco. Knowing full well the bottom's going to drop out any day now."

[Jewel says:] "They're trapped."

"They're trapped." (p.122)

Tobacco is by no means an easy option. Not only does it entail debt but the economics and ethics do not add up, as Lusa notes:

"Farm economics, what do I know? But half the world's starving, Jewel, we're sitting on some of the richest dirt on this planet, and I'm going to grow drugs instead of food? I feel like a hypocrite. I nagged Cole to quit smoking every day of our marriage. (p.122)

The challenge Kingsolver sets Lusa is to find some other way to make the farm unit work. Amidst living with her grief and adjusting to life in Zebulon County, Lusa tries to find an answer to questions many small-scale farmers are facing today:

"Well, farming. You know, you've got to do what it takes."

"Yep. And around here that's tobacco, I guess, if I want to keep this farm. I

just wish I could be the one person to think of a door out of that trap." (p.123)

It should be clear what backdrop Kingsolver has in mind here. It is small-scale farmers, often but certainly not exclusively in contract farming mechanisms that tie them into long-term indebtedness; or facing a squeeze upstream of their farm businesses from suppliers of agrichemicals and seeds, as well as downstream from buyers, processors and retailers (e.g. see 
Weis, 2007). It is, in short, the struggle of the so-called family farmer versus capitalist agriculture, a struggle over whether agriculture is going to be treated like other forms of capitalist production (see also Jones, 2006). The prospects of just such a scenario going global from the farms of the United States generates nightmarish fears among critics such as Samir Amin (2003), whose perspective seems to connect with Kingsolver's rural imaginary:

... what would happen if agriculture and food production were treated as any other form of production submitted to the rules of competition in an open and deregulated market, as decided in principle at the November 2001 WTO meeting in Doha. Would such principles foster the acceleration of production? One can imagine that the food brought to market by today's three billion peasants, after they ensure their own subsistences, would instead be produced by twenty million new modern farmers. The conditions for the success of such an alternative would include: (1) the transfer of important pieces of good land to the new capitalist farmers (and these lands would have to be taken out of the hands of present peasant populations); (2) capital (to buy supplies and equipment); and (3) access to the consumer markets. Such farmers would indeed compete successfully with the billions of present peasants. But what would happen to those billions of people?

By focusing on Lusa's trap, Kingsolver calls attention to the situation facing many other small-scale farmers in rural Appalachia, elsewhere across the US, and indeed globally. The novel therefore connects with a much broader process in which agribusinesses, often supported by agricultural extension services, push forward so-called 'agricultural modernization', which in turn often leads to indebtedness, bankruptcy, and farm-size 
consolidation. Such a process evidently transforms rural space and more fully subsumes its ongoing formation to the logic of capitalist accumulation, whether neoliberal or not. But whereas Amin's nightmare scenario is that this process will replace three billion peasants with twenty million capitalist farmers, Kingsolver's sense of rural space is that (at least) some individuals can resist that process.

Thus, here at the 'meso' scale of the novel, between the macro scale of the mountain and the micro scale of the fence, Lusa encounters a trap and struggles to find a door out of it. What Lusa takes on and eventually achieves is certainly dramatic and inspirational; but Kingsolver's scalar poetic ensures we understand that Lusa's resistance against normalized practices is not by any means an isolated occurrence in Zebulon County. Furthermore, her exploration in the other sub-plots of the general and the more specific makes it possible for readers to more fully appreciate the sort of context in which Lusa's practices of resistance unfold. Traps and resistance also matter at the other scales of the novel. In the constant background of Deanna's story on the mountain, for example, is her fear of hunters trapping and shooting the coyotes that recently moved into the county, as well as her fears of becoming trapped by her love for Eddie (Kingsolver, 2000 p.99). And as the next sub-section discusses, Kingsolver uses Nannie's story at the micro scale of the novel to explore other tensions that help readers understand the magnitude of Lusa's battle to transform her farm business.

\subsection{Nannie and addiction}

The second of the three key moments at issue in this paper occurs midway through the book. Nannie is arguing with her neighbour, Garnett Walker, whose use of chemicals affects her organic orchard. Throughout the recounting of their arguments, Kingsolver brings readers right down to the micro scale of the fence that joins and divides them. Indeed, this 
contradictory unity between them is critical to the way Nannie's story develops. Nannie and Garnett have vastly opposing thoughts about the natural world. Nannie makes few assumptions about the earth and sees herself as just one actor in the making of the spaces around her. In contrast - and even though he has struggled for years to nurture old chestnut trees that died out via "ax or blight" (Kingsolver, 2000 p.2) - Garnett still believes he is master of his land, someone with powers to shape and control nature. This view of the world validates his decision to spray herbicides and insecticides, despite lingering suspicions that such spraying might have caused his late wife's lung cancer. In an attempt to reduce Garnett's use of chemicals, Nannie appeals to him: "What we need is to have a good, levelheaded talk about this pesticide business, farmer to farmer" (Kingsolver, 2000 p.273). She then uses the opportunity to cite evidence from Orchardman's Journal that broad-spectrum pesticides boost "the numbers of the bugs you don't want and wip[e] out the ones you need. And every time you spray, it gets worse" (p.275).

"And then?" Garnett asked, concentrating on this.

She looked at him. "And that's it, I'm done. The Volterra Principle."

Garnett felt hoodwinked. How could she do this every time? In another day and age they'd have burned her for a witch. "I didn't find the fault in your thinking," he admitted.

"Because it's not there! she cried. "Because I'm right!" The little woman was practically crowing.

"The agricultural chemical industry would be surprised to hear your theory." "Oh fiddle, they know all about it. They just hope you don't. The more money you spend on that stuff, the more you need. It's like getting hooked on hooch." (p.275; my emphasis) 
In this final statement, Kingsolver calls attention to the danger of using agri-chemicals, of becoming trapped on a treadmill of technological fixes, a treadmill on which so many contemporary farmers are stuck (Weis, 2007). Like Deanna's fear of hunters trapping and shooting the coyotes she wants to protect, and Lusa's worries about the trap of tobacco farming, Nannie is highly aware of the structural and global constraints she faces. But via her relations with Garnett she knows they are also hyper-local, micro scale. Here at the micro scale of the novel, across a fence, two neighbours with opposing views of how to make the rural space they help constitute argue over the terms of their close relationship, one heavily defined by Garnett's sense that he needs to keep spraying pesticides and Nannie's anger at his practices. Kingsolver lets Nannie look across her fence and see a foe, but Nannie also sees a potential ally: she sees scope to do something, an opportunity to make a change that will impact positively on her.

It is the precise tension this opportunity entails for Nannie (and others who want to see positive changes in their lives) that Kingsolver seems to want readers to dwell upon. On the one hand, this is about a politics of conflict, of challenging accepted wisdom, firmlyembedded assumptions, because Nannie has to tackle Garnett and try to change his practices. But on the other hand, her prospects of success also hinge on working with Garnett. She cannot only refuse and oppose his actions; she must also find ways of cooperating across the fence that divides them, hence she shares various forms of knowledge with him, even though this entails hearing his scorn and condescension. In time, Nannie begins to get somewhere: by the novel's end, they are far more neighbourly towards each other than they ever were. 
I argue that Kingsolver's focus on this micro scale of action enables her to communicate a general point about acts of resistance that, in turn, help readers grasp Lusa's story. Certainly, Nannie and Lusa both need to challenge broader structures (both aim to farm organically, despite all the pressures on them to farm in a so-called conventional way), but Kingsolver uses Nannie's story to propose that challenging the existence and products of corporate power, say, also means tackling neighbours (which Lusa might also need to do in future years). After all, the striking feature of Nannie's reaction to the hooch of agri-chemicals and the structures that make their production and consumption so pervasive is exactly that her local acts are truly horizontal and occurring at the boundaries of her domain. Whereas the message here resembles the 'act locally' mentality, which inspires many people to alter the geographical configuration of forces in their localities; the value of considering what works for Nannie is that acting locally cannot only mean acting alongside others in a locality but also that there are real gains to be made from trying to change those in close, close proximity. Opposing and subverting dominant processes and actors shaping the contemporary global politics of the rural entails this horizontal act of speaking to those in close proximity, especially because their precise proximity provides scope to communicate and speak, if not necessarily to be heard. The hooch Nannie wants to avoid may not be an addiction every rural actor wants to steer clear of, but her determination is matched with a compulsion to move (and move with) those nearby, not just distant networked others in a (transnational) social movement (e.g. Borras et al. 2008; Borras, 2010; Woods, 2008). The power of Kingsolver's scalar poetic is certainly that it helps her explain the significance of Lusa's successes, but it also sheds light on the sorts of realities facing actors at the micro scale, right across the fence that divides and connects them to others.

\section{Causality and the underlying geography of Prodigal Summer}


In the process of constructing the social world in which Prodigal Summer takes place, Kingsolver lets the action occur at three geographical scales - the mountain, the farm unit, and the fence. At the macro scale of the mountain, readers encounter the general backdrop to the stories: the socio-environmental history of the U.S. and the various ruptures or shifts that have changed that place. At the meso scale, on Lusa's farm unit, readers learn about the constraints facing Lusa as she tries to act against what her in-laws believe she should do, against the normalized agricultural practices in the area. And over Nannie's fence with Garnett, at the micro scale, Kingsolver explores the dynamics and tensions of neighbourly relations via the struggle Nannie faces to keep her orchards free of her neighbour's chemicals.

Cutting across, wandering through, and in the background of these three arenas are numerous ecological and social processes. On the mountain, for example, there is the movement of wildlife, of bats and birds, as well as air and smells and sounds from the valley below; as well as the presence in the background of CNN, Disney, the mainstream world of news and entertainment that Deanna, at least, wants nothing of. In these sorts of ways, Kingsolver imagines and depicts rural Zebulon County and how it is produced. She sees the tensions and conflicts; the domination and resistance that necessarily constitute the place. In short, she imagines a particular sort of geography and much of the novel is used to explain how it shapes - and is shaped by - her characters.

In line with the first opening of the text, the places and spaces of Prodigal Summer - as well as the constellation of relations lurking behind and emerging from the text - are open to an unknowably open range of interpretations and meanings. But in asking about what happens in the novel and why it happens, a second opening of the text emerges. What is causing the central, most dramatic processes to unfold in the way they do is not just what Kingsolver 
writes; rather, the spatial event of the text makes it possible for readers to dwell upon and make use of the unwritten world that unfolds inside the text but, as it were, off-stage. To grasp this point, the central concern has to be Lusa's success and the sovereignty she develops over the land, which comes together in the third and final moment at issue in this paper.

\subsection{Lusa's sovereignty}

Lusa manages to make it through the summer. Unlike so many other small-scale farmers who never find a way to beat the system they confront - unlike her late husband, who "tried red bell peppers one year and cucumbers the next, potatoes the next" (Kingsolver, 2000 p.123) she develops a farm adjustment strategy (e.g. see Ilbery, 1991) that entails creating a viable new and radically different farm business based, at least for this first summer, on rearing organic goats for sale in New York. It seems to work, although the fall and the winter are not part of the book, hence readers cannot be certain of Lusa's fate. Nevertheless, the summer has changed her. Most notably, Lusa's newfound confidence and sense of security engenders in her a new connection to Cole's family. Lusa was distant from her in-laws when she first arrived to the farm, in part because her sensibilities (for example regarding whether Lusa should take Cole's last name) clashed with theirs. But towards the end of the novel she has developed more loving relations with them and these new bonds lead her to make a bold decision.

As the inheritor of the farm, Lusa obviously has the legal right to decide what to do with it. But Kingsolver develops in Lusa a peculiar and progressive understanding of her relationship to the land. This comes together in a critical moment towards the end of the book after Lusa discovers that Jewel, her sister-in-law, has terminal cancer. Knowing that Jewel's children will 
face an uncertain material future, not least because their absent father has an irregular and low income, Lusa offers to adopt them and put their names on the deeds to the farm:

"So it would go to them, you know, after me." She felt a strange movement in the air as she said this, a lightness that grew around her. When she gathered the will to look up at Jewel again, she was surprised to see her sister-in-law's facing shining with tears.

"It just seems right to do that," Lusa explained, feeling self-conscious. "I'm thinking I'd add 'Widener' to their names, if that's all right with you. I'm taking it, too."

"You don’t have to. We all got over that." Jewel wiped her face with her hands. She was smiling.

"No, I want to. I decided a while ago. As long as I live on this place, I'm going to be Miz Widener, so why fight it?" Lusa smiled, too. "I'm married to a piece of land named Widener." (Kingsolver, 2000 pp.382-383).

The obvious gain for her in-laws in the Widener family is that the land will remain close to them. They initially feared that Lusa would sell up and move on, or stay and re-marry. But Lusa has been changed by the summer's events; by the way she has navigated her new life in rural Zebulon County. She has gained confidence from her decisions and actions and this has helped her find love for Cole's family:

"[It is] [f]or Cole, the kids, all of you. The family. I don't know. . . . It just seems like the thing to do. So this farm will stay where it is on our little map of the world. It's an animal thing, I guess. Marking a territory." (p.418) 
This is clearly a bold and brave move. The decision goes against her initial stance towards changing her name after marriage. And adoption under the approaching circumstances will be extraordinarily difficult. Her decision also profoundly ties her to the land. But what seems to be crucial here is that Lusa makes the decision based on a sense of security that her resistance against normalized practices (rearing goats rather than growing tobacco) can yield a good future. She now has legal title but also a sense of sovereignty. However, Lusa's sovereignty over the land is not absolute. She is not just a landowner, not just someone with a title deed, but rather has a deeper relation with the land and its non-human constituents (Kingsolver, 2000 p.413):

"In all her troubles she had never yet stopped to consider her new position: landholder. Not just a mortgage holder, not just burdened, but also blessed with a piece of the world's trust."

The key point here is that Lusa finds and develops this sensibility via her practices of resistance against a geographical configuration - at broader and finer geographical scales, as readers learn from the stories about Deanna and Nannie - that seeks to close off her options. Her success brings her a level of independence and confidence. Resistance bears fruit. But helping readers grasp this tempered sovereignty is that the rural geography Kingsolver constructs around Lusa combines with an unwritten, off-stage geography that readers are open to ponder by virtue of the second opening of the text.

Consider, for example, how Kingsolver explains Lusa's success. Her Polish and Palestinian background means she has knowledge of diverse religious practices, which leads her to 
realize that her cousin in New York will be on the lookout for goats in the coming year. As Lusa points out to her nephew, "Two huge goat-feast holidays are coming up, together, at the very end of the year. And that means Id-al-Adha will be - February, March - early April! The same time as Orthodox Easter and Passover" (p.160). Assembling goats leftover across the country from a long-completed school project, knowledge about rearing them from her family and others across the county, including from Garnett Walker, Lusa thereby slowly begins to transform her farm business, all with an eye on a distant market. It is also significant that Lusa has a scientific background - that she is akin to a "globally engaged farmer" (Cheshire and Woods, 2013) - and can imagine how the methods she will adopt might begin to yield positive outcomes; she is determined, strong, and hard-working.

Lusa navigates and negotiates an inherently open rural space. There is, for example, the way rurality is constituted by her own biography: her family's religious background, her transnational identity, and her knowledge of those relations which she mobilizes to pursue changes on her farm. Then there is the way Zebulon County has been shaped by its openness to flows of settlers, fungal blight (which "stepped off a ship in some harbor, grinned at America, and took down every chestnut tree from New York to Alabama." [Kingsolver, 2000 p.100]), as well as new entrants such as the coyotes and Eddie Bondo. In the sense that this rural space is so intensely open, Zebulon County resembles a "transrural" space (Askins, 2009), one constituted by transnational relations, by distant others, as well as geo-histories of non-human and human migration (and the concomitant identity politics that the latter play their part in the production of space, rural or not). Without question, avoiding the trap of tobacco farming hinges on Lusa's transrural positionality, on her ability to take advantage of the opportunities coming her way; her success is achievable - it is believable - precisely because Kingsolver constructs a stretched out and open rural geography in which Lusa can 
navigate contingency, make use of goats unwanted by her neighbours (as well as draw on their knowledge), and ultimately move the commodities she produces to distant markets. There is a particular spatial configuration in Prodigal Summer of characters, geographies, and diverse processes, as of course we should expect from a novel, indeed from any novel.

But in addition to the geography Kingsolver presents, and as per the idea of a second opening of the text, it is also important to note here that causality in Prodigal Summer is not just a product of what readers encounter on the page. Rather, there are numerous off-stage factors to consider. New York, for example - where "it's all people, eating all the time" (Kingsolver, 2000 p.164) - has become something different over the years. There is a new demand for organic or humanely-reared meat, which in turn creates opportunities for rural producers. Kingsolver need not and indeed does not dwell upon this. Yet without New York, without its wealth and its internal diversity, Lusa's summer might never have been so prodigious. There is this inevitability of difference and chance - the "happenstance juxtapositions" that are so important in the production of space (Massey, 1999) - and it helps Lusa. What exists in the backdrop, then, in a sense off-stage, is a highly contested, differentiated rural space constituted as much by the ordinary everyday relations of individual actors, such as Lusa, as by the locality-specific makers of "rural power" (Bell et al, 2010), or the corporate giants who lurk in the background of the text (and in the background, too, of Kingsolver's sense of rurality e.g. see Jones, 2006: 86-87). Proximate and distant actors - written and unwritten actors and events and processes - shape Zebulon County.

This unwritten constellation of relations is open to interpretation. And one way to make sense of it is to consider the significance of Lusa's summer. By adopting her sister-in-law's children and then developing a new relationship with the land she owns, Lusa makes a decision that 
forces readers to consider anew understandings of landownership and the sorts of rationalities drawn upon by people who work the land. Many readers of Prodigal Summer will relate to and understand most closely Lusa's initial feelings about the land: the land as a commodity, as an asset or a financial strain, as a burden. But the other stance, the land as a blessing, seems to be a more postcolonial notion of landholding and one that connects this one woman in the rural US with peasant- and farmer-activists who, for the last twenty years, have called for a type of rural space that operates according to principles of 'food sovereignty', rather than just returns on investment. Intentionally or not, by presenting Lusa's new sense of sovereignty in this way, Kingsolver locates her beside the food sovereignty movement, one driven forward by differentiated and diverse activists "who share a deep commitment to place, people deeply attached to a particular piece of land, people who are all part of a particular rural community, people whose mode of existence is under threat" (Desmarais, 2008 p. 140; see also Borras, 2010).

Politically, then, what Kingsolver achieves here is dramatic. An unwritten feature of the geography of Prodigal Summer locates the rural US alongside and contemporaneous with rural Chile, rural Indonesia, or even rural Congo (the setting for Kingsolver's best-selling novel The Poisonwood Bible). Globally, and as Samir Amin's nightmare highlighted, other small-scale farmers like Lusa are engaged in similar battles to stay on the land, to manage to hold on to relations with the land in more-than-material ways. Via her acts of resistance and the confidence she gains from moving in a direction she believes is ethical, Lusa develops a degree of loyalty to the land; an 'always-in-the-process-of-becoming' (Massey, 1999) bond that shapes her decisions in ways that capitalist agriculture (and state-led visions promoting forms of 'modern' agriculture) necessarily seeks to ignore, undermine, and displace. Within Prodigal Summer, therefore, readers might gain a sense that, even in the so-called 'advanced 
capitalist' United States, there is a "Greater America" (Jacobson, 2010) constituted by people with sensibilities shared by distant others resisting similar sorts of processes originating from the same contemporary global politics of the rural. Not only is there an on- and off-stage openness causing change in Prodigal Summer, but the changes themselves and their broader significance beyond the novel encourage readers to re-imagine contemporary rural geographies.

\section{Conclusion}

'Upstream' of releasing her books, Kingsolver takes on a lot. She is "critically engaged" (Jacobson, 2010 p.194) and willing to imagine geographies by creating "politically viable" "utopian maps" (p.197) that can "visualise for the reader the ways in which history, geography, and identity converge" (p.198). In Prodigal Summer, her imagined rural Zebulon County, firmly located in the US but not bound by that location, asks readers to confront problematic processes producing projects and practices that simultaneously constrain actors such as Lusa, but also open up opportunities for them to resist and pursue "politically viable" alternative realities. In the making of her imagined social world, Kingsolver presents a vision of rurality in which diverse actors try to create spaces that suit their rationalities, although rarely without contestation and never only on their own terms (as Kingsolver makes clear via her constant reference to the lives of flies, spiders, snakes, and other species who always share space alongside the human characters).

Part of the 'downstream' significance of Prodigal Summer, it seems to me, is that the story occurs in a space where the contemporary global politics of the rural are unmistakably at work. Present in the novel are the sorts of negative forces that worry Kingsolver: predatory agri-chemical corporations in the guise of Garnett Walker; pressures on farmers to work off- 
farm or even leave the land altogether, as Cole's shortened life demonstrates; and exploitative recreational users of rural space, such as the hunter Eddie Bondo. Their presence demonstrates Kingsolver's awareness of the problematic way rural space is emerging. But reflecting her sense that the rural is an open space of opportunity, that it is not somehow lacking (e.g. see Short, 1991), Kingsolver constructs a fictional rural space in which Lusa can resist the pressure to grow tobacco and instead craft a brighter future more attuned to her sensibilities. She arrives, is widowed and has the option of leaving; but she fights and makes a commitment not only to staying but to re-making the slice of rural space she now occupies. Lusa embodies the sense that rural space also offers opportunity; that it is not to be left behind, that it is not trailing the city somehow. Thus, in introducing and developing optimistic stories around Lusa and two other strong women who demonstrate the possibilities that exist for actors to produce new, better realities, we learn that the contemporary global politics of the rural might not necessarily lead to Samir Amin's nightmare vision; that, instead, new visions might still be able to emerge. Moreover, in imagining an underlying rural geography that could yield the sensibilities Lusa discovers - a geography that makes Lusa's success possible - Kingsolver demonstrates the open futures that exist today, notwithstanding the pressures that her three central characters encounter. Ultimately, on the mountain, a farm, and over a fence, Prodigal Summer illustrates that people like Deanna, Nannie and Lusa can "craft solutions" amidst "uncertainty and contingency" (Leder, 2009 p.242). In this regard, if Short (1991 p.177) was right to call attention to the death of the authentically rural novel in the 20th century, Kingsolver stands out as a prominent gravedigger, someone whose vision of an open, engaged, and promising rurality - albeit one facing multiple crises - deserves attention from scholars of rural studies.

\section{References:}


Akram-Lodhi, A.H. 2012. Contextualising land grabbing: contemporary land deals, the global subsistence crisis and the world food system. Canadian Journal of Development Studies 33, pp.119-142.

Amin, S. 2003. World poverty, pauperization \& capital accumulation. Monthly Review. URL http://monthlyreview.org/2003/10/01/world-poverty-pauperization-capital-accumulation [online] [accessed 23/09/13]

Askins, K. 2009. Crossing divides: Ethnicity and rurality. Journal of Rural Studies 25, pp.365-375.

Bell, M. M., Lloyd, S. E., Vatovec, C. 2010. Activating the countryside: Rural power, the power of the rural and the making of rural politics. Sociologia Ruralis. 50, pp.205-224.

Borras, S.M. Jr. 2010. The politics of transnational agrarian movements. Development and Change 41, pp.771-803.

Borras, S.M. Jr., Edelman, M., Kay, C. 2008. Transnational agrarian movements: Origins and politics, campaigns and impact. Journal of Agrarian Change 8, pp.169-204.

Brosseau, M. 2009. Literature. In Kitchin, R \& N. Thrift (eds) The International Encyclopedia of Human Geography. Elsevier, London, pp.212-218.

Cheshire, L. Woods, M. 2013. Globally engaged farmers as transnational actors: Navigating the landscape of agri-food globalization. Geoforum 44, pp.232-242. 
Crang, M. 2009. Commentary on: Text as it happens: Literary Geography. Compass Interdisciplinary Virtual Conference. URL

http://compassconference.files.wordpress.com/2009/10/civc-commentary-michael-crang-

durham-university-on-text-as-it-happens-literary-geography-sheila-hones.pdf [online]

[accessed 15/2/2014]

Darling, E. 2005. The city in the country: wilderness gentrification and the rent gap.

Environment and Planning A 37, pp.1015-1032.

Desmarais, A.A. 2008. The power of peasants: Reflections on the meanings of La Via Campesina. Journal of Rural Studies. 24, pp.138-149.

Dick, P.K. 1965 [1962]. The Man in the High Castle. Penguin, London.

Edquist, H. 2009. Precise and imprecise geographies in Christina Stead's Seven Poor Men of Sydney. The Cartographic Journal 46, pp.343-349.

Evans, N. 2009. Adjustment strategies revisited: Agricultural change in the Welsh Marches. Journal of Rural Studies 25, pp.217-230.

Gore, A. 2006a. An Inconvenient Truth: The planetary emergency of global warming and what we can do about it. Bloomsbury, London.

Gore, A. 2006b. An Inconvenient Truth. Paramount Studios. 
Hanson, S. 2010. Celebrating a lively earth: Children, nature, and the role of mentors in Prodigal summer. In: Leder, P. (ed.) Seeds of change: Critical essays on Barbara Kingsolver. University of Tennessee Press, Knoxville, pp.252-262.

Hones, S. 2008. Text as it happens: Literary Geography. Geography Compass, 2/5 pp.13011317.

Hones, S. 2011. Literary geography: Setting and narrative space. Social and Cultural Geography, 12 pp.685-699.

Ilbery, B.W. 1991. Farm diversification as an adjustment strategy on the urban fringe of the West Midlands. Journal of Rural Studies 7, pp.207-218.

Jacobson, K.J. 2010. Imagined geographies. In: Leder, P. (ed.) Seeds of change: Critical essays on Barbara Kingsolver. University of Tennessee Press, Knoxville, pp.175-198.

Jones, S.W. 2006. The Southern family farm as endangered species: Possibilities for survival in Barbara Kingsolver's Prodigal Summer. xxxix, pp.83-97.

Kearns, G. 2005-2006. The spatial poetics of James Joyce. New Formations 57, pp.107-125.

Kingsolver, B. 1998. The Poisonwood Bible. Faber and Faber, London.

Kingsolver, B. 2000. Prodigal Summer. Faber and Faber, London. 
Kingsolver, B. 2012. Flight Behaviour. Faber and Faber, London.

Livingstone, D.N. 2005. Text, talk and testimony: geographical reflections on scientific habits. An afterword. British Journal for the History of Science 38, pp.93-100.

Leder, P. 2009. Contingency, cultivation, and choice: The Garden Ethic in Barbara Kingsolver's Prodigal Summer. Interdisciplinary Studies in Literature and Environment 16, pp.227-243.

Massey, D. 1999. Spaces of politics. In: Massey, D., Allen, J., Sarre, P. Human Geography Today. Polity, Cambridge, pp.279-294.

McMichael, P. 2008, Peasants make their own history, but not just as they please .... In: Borras, S.M. Jr., Edelman, M., Kay, C. (Eds.) Transnational agrarian movements. WileyBlackwell, Oxford, pp.37-60.

McMichael, P. 2012. The land grab and corporate food regime restructuring. Journal of Peasant Studies 39, pp.681-701.

Moyo, S., Yeros, P. 2005. The resurgence of rural movements under neoliberalism. In: Moyo, S. and Yeros, P., (Eds.), Reclaiming the land. Zed, London, pp.8-64.

Phillips, M. 1993. Rural gentrification and the processes of class colonization. Journal of Rural Studies 9, pp.123-140. 
Phillips, M. 2004. Other geographies of gentrification. Progress in Human Geography 28, pp.5-30.

Piper, N. 2013. Audiencing Jamie Oliver: Embarrassment, voyeurism and reflexive positioning. Geoforum 45, pp.348-355.

Petras, J. 2006. 'Centre-left' regimes in Latin America: History repeating itself as farce? Journal of Peasant Studies 33, pp.278-303.

Pollan, M. 2008. In Defence of Food: The myth of nutrition and the pleasures of eating. Allen Lane, London.

Saunders, A. 2010. Literary geography: Reforging the connections. Progress in Human Geography 34, pp.436-452.

Short, J.R. 1991. Imagined Country. Syracuse University Press, New York.

Stead, C. 1999. Seven Poor Men of Sydney. ETT Imprint, Sydney.

Weis, A.J. 2007. The Global Food Economy: The battle for the future of farming. Zed, London.

Wenz, P.S. 2003. Leopold's novel: The land ethic in Barbara Kingsolver's Prodigal Summer. Ethics and Environment 8, pp.106-125. 
White, B., Borras, S.M. Jr., Hall, R., et al. 2012. The new enclosures: critical perspectives on corporate land deals. Journal of Peasant Studies 39, pp.619-647.

Woods, M. 2008. Social movements and rural politics. Journal of Rural Studies 24, pp.129137.

World Bank. 2008. World Development Report 2008: Agriculture for Development. World Bank, Washington, DC.

Zoomers, A. 2010. Globalisation and the foreignisation of space: seven processes driving the current global land grab. Journal of Peasant Studies 37, pp.429-447. 